\title{
APPLICATION OF THE GENERAL CLAUSE OF REASONABLENESS AND CRITERION OF RATIONALITY IN POLISH TAX LAW
}

\author{
Monika Münnich*
}

\begin{abstract}
This paper's objective is to present two methods of introducing elements of the civil general clause of reasonableness into tax law. One of them is the lawmaking process, the other is the application of law, i.e. the decisions of tax authorities and the jurisprudence of national administrative courts.
\end{abstract}

Keywords: general clause reasonableness, rationality, tax avoidance, tax deductible costs

\section{INTRODUCTION}

In some areas of legal norms of European law a new clause of reasonableness has been frequently encoded since the early eighties of the twentieth century. This clause is derived from traditional equity general clauses developed in the common law system ${ }^{1}$. A characteristic feature of the clause of reasonableness or, in other words, of practical rationality

Dr. habil. Monika Münnich, Assistant Professor, Faculty of Law, Canon Law and Administration, The John Paul II Catholic University of Lublin; correspondence address: Al. Racławickie 14, 20-950 Lublin, Poland; e-mail: mmunnich@kul.pl; https://orcid. org/0000-0002-9250-5748.

1 Vide: Ewa Rott-Pietrzyk, "Holenderska klauzula rozsądku i słuszności na tle innych uregulowań prawnych (wzór dla polskiego ustawodawcy?)," Przeglad Prawa Prywat- 
is the lack of direct reference to the universal moral and ethical criteria and values typical of bona fides, such as honesty and mutual trust, diligence, truth and equity ${ }^{2}$. This clause refers to ethically coloured rationality, or more precisely to the measure, which is the most effective conduct according to the current state of knowledge, aimed to achieve specific results, considering moral values, and thus what is fair in certain circumstances. According to some representatives of Polish civil literature in case of clauses of reasonableness, as opposed to traditional equity clauses, the reasonableness criterion allows for an objective assessment of contractual integrity, especially with regard to the objective reconstruction of the catalogue of obligations incumbent on the parties, enabling them to balance mutual interests ${ }^{3}$. It is also asserted in this literature that the clause of reasonableness can be said to be a "place and time" clause understood socially, because reason is what everyone believes to have to an appropriate degree ${ }^{4}$.

It seems that the first legal act in which the general clause of reasonableness was applied was the Vienna Convention of 1980 on contracts for the international sale of goods $s^{5}$. However, it should be noted that the criterion of reasonableness had already appeared in the Hague Convention of $1964^{5}$. This clause is also reflected in the Principles of European Contract Law,

nego, no. 3 (2006): 57-101; Andrzej Bierć, Zarys prawa prywatnego. Część ogólna (Warsaw: Wolters Kluwer 2018), 44, 50 and 71.

2 C.f.: Krzysztof Amielańczyk, "W poszukiwaniu antycznej genezy klauzul generalnych, czyli o wartościach i wartościowaniu w prawie rzymskim," Annales Universitatis Mariae Curie-Sklodowska Lublin-Polonia, no. 2 (2016): 32.

3 The possibility of dichotomous recognition of good faith in an objective and subjective aspect is raised as a defect in national literature. Vide: Kazimierz Piasecki, Kodeks cywilny. Księga pierwsza. Część ogólna. Komentarz (Warsaw: Wolters Kluwer, 2003); Małgorzata Pyziak-Szafnicka, "Komentarz do art. 7," in Kodeks cywilny. Komentarz. Część ogólna, eds. Małgorzata Pyziak-Szafnicka, and Paweł Księżak (Warsaw: Wolters Kluwer, Lex 2014).

Andrzej Bierć, Zarys prawa prywatnego. Część ogólna, 105-106.

5 This convention uses the term a reasonable person, vide: Ewa Rott-Pietrzyk, "Pojęcie rozsądku w projekcie Europejskiego Kodeksu Cywilnego," in Rozprawy prawnicze. Księga pamiattkowa Profesora Maksymiliana Pazdana, eds. Wojciech Popiołek, Leszek Ogiegła, Maciej Szpunar (Cracow: Zakamycze, 2005), 706. 
which constitute the stem of the European Civil Code ${ }^{6}$ and in the Rules of International Trade Agreements, UNIDROIT ${ }^{7}$. All these documents contain the key phrases characteristic of reasonable clauses: reason, reasonable time or a reasonable person ${ }^{8}$. Definitely the biggest supporters of introducing general clauses based on the criterion of reasonableness and equity into the European Union legal system are the Dutch - the creators of the Dutch Code of Civil Law, from which in 1992 they definitively deleted the general clause good faith. As a result of these legislative changes in Dutch contract law, in case of interpretation of declarations of will, the basic evaluation standard is currently the model of a reasonable and honest man (reasonably prudent person) whose conduct should be protected (reasonable person test $)^{9}$. The new general clause is closely connected with the so-called New

6 The Principles Of European Contract Law 2002 (Parts I, II, and III) European Union, (PECL), https://www.jus.uio.no/lm/eu.contract.principles.parts.1.to.3.2002/ (access date: 3.07.2019). See more widely: Ewa Rott-Pietrzyk, "Pojęcie rozsądku w projekcie Europejskiego Kodeksu Cywilnego," 701-718.

7 Interpretation of Statements and Other Conduct z 1994. See more widely e.g.: Monika Pacocha,"Zastosowanie zasad międzynarodowych kontraktów handlowych UNDROIT jako ogólnych zasad prawa oraz lex mercatoria," https://repozytorium.amu.edu.pl/bitstream/10593/13559/1/14_PACOCHA.pdf (access date: 3.07.2019).

8 Vide: art. 4.2. Interpretation of Statements and Other Conduct, 1994: 1. The statements and other conduct of a party shall be interpreted according to that party's intention if the other party knew or could not have been unaware of that intention. 2. If the preceding paragraph is not applicable, such statements and other conduct shall be interpreted according to the meaning that a reasonable person of the same kind as the other party would give to it in the same circumstances. Similarly, see: 1:302 PECL: Under these Principles reasonableness is to be judged by what persons acting in good faith and in the same situation as the parties would consider to be reasonable. In particular, in assessing what is reasonable the nature and purpose of the contract, the circumstances of the case, and the usages and practices of the trades or professions involved should be taken into account.

9 Cf.: Ewa Rott-Pietrzyk, "Wzorzec rozsądnej osoby w świetle Konwencji wiedeńskiej o umowach międzynarodowej sprzedaży towarów," Rejent, no. 9 (2005): 202-222; Ewa Rott-Pietrzyk, "Pojęcie rozsądku w projekcie Europejskiego Kodeksu Cywilnego", 705; Andrzej Bierć, Zarys prawa prywatnego. Część ogólna, 106; Natalia Bukowska, "Klauzula rozsądku w anglosaskim prawie ubezpieczeniowym oraz Restatement of European Insurance Contracts", https://docplayer.pl/7021643-Klauzula-rozsadku-w-anglosaskim-prawie-ubezpieczeniowym-oraz-restatement-of-european-insurance-contracts.html (access date: 4.07.2019). 
European Legal Culture, whose main characteristics is to deny the legitimacy of contemporary reference not only to the values associated with Europe's Judeo-Christian roots, but above all to the tradition and culture of the ius romanum ${ }^{10}$.

In Polish private law, the general clause of reasonableness has been regulated so far in several provisions of the Civil Code ${ }^{11}$. According to some representatives of the literature, the introduction of clauses based on a reasonable criterion to international, European and national provisions is part of the humanisation of contractual civil law, as it has unduly restricted the favored principle of safety of trade at the expense of its participants'interests $^{12}$.

\section{REASON - STRUCTURAL COMPONENTIN THE PROVISIONS OF GENERAL TAX LAW}

In current Polish tax law regulations, the typical assessment criteria for the clause of reasonableness, such as reason and rationality, are included in

10 See more widely on reducing the influence of Roman law on new codifications and institutions in civil law: Stephanie Law, "From Multiple Legal Cultures to One Legal Culture Thinking About Culture Tradition and Identity in European Private Law Development," Utrecht Journal of International and European Law, no. 31 (2015): 68-89, http:// doi.org/10.5334/ujiel.dg (access date: 4.07.2019); Martijn W. Hesslink, The New European Private Law (Deventer: Wolters Kluwer, 2001); Pier Giuseppe Monateri, Tomasz Giaro, Alessandro Somma, Le radici comuni del diritto europeo. Un cambiamento di prospettiva (Rome: Carroci Editore, 2005). See also: Wojciech Dajczak, Dobra wiara jako symbol europejskiej tożsamości prawa (Poznań: Wydawnictwo Świętego Wojciech, 2006).

11 In Polish regulations, the criterion of reasonableness was normalized impersonally using such legal phrases as: reasonable time, reasonable assessment, reasonable kontent in art. $561 \$ 2$; art. $7602 \$ 2$; art. $7602 \$ 3$; art. $761 \$ 2$ i art. 7611 ; art. $948 \$ 2$ of the Act on the Civil Code of 23 April 1964, Journal of Laws 2019, item 1145, as amended. These provisions regulate the interpretation of a will that allows the testator's orders to be upheld and give them reasonable content. In the personal form, however, the reasonableness clause was also regulated in art. $84 \$ 2$ of the Civil Code, i.e. in the provisions regarding the determination of the significance of an error as a defect in a declaration of intent in which the expression occurs, assessed the case reasonably.

12 C.f.: Ewa Rott-Pietrzyk, "Pojęcie rozsądku w projekcie Europejskiego Kodeksu Cywilnego," 707. 
the provisions of the Tax Ordinance. The first one (reason) was introduced into this Act along with the so-called anti-tax avoidance clause ${ }^{13}$, and it can be found in the following provisions:

1. an appropriate conduct is one that an entity could under certain circumstances be engaged in, if it was conducted reasonably and was guided by lawful purposes other than gaining tax advantage contrary to the object or purpose of the Tax Act or its provision, and the mode of conduct would not be artificial ${ }^{14}$,

2. the mode of conduct is not artificial, if on the basis of existing circumstances it should be assumed that an entity, acting reasonably and legally, would use this mode of conduct predominantly for clearly justified economic reasons ${ }^{15}$;

3. the assessment that the mode of conduct was artificial may be provided in particular by the occurrence of:... economic risk exceeding the expected non-tax benefits to such an extent that it should be considered that this conduct would not have been chosen by a reasonably operating entity ${ }^{16}$.

It should be added that the normative model on which the Polish legislator relied directly was the British anti avoidance general clause, referring to the notion of reasonableness ${ }^{17}$.

Apart from the provisions applicable since 2016, the expression of reasonableness (referring to circumstances and conditions) was used in regulations added to the new tax provisions governing so-called additional liability. Under these provisions: the assessment that the taxpayers acted in good faith can be proved by the fact that they did not run any business

13 Vide: Section IIIa The Act on the Tax Ordinance of 29 August 1997, Journal of Laws 2019, item 900 as amended. The section was introduced by the Act on the amending the Act - Tax Oridnance and some other acts of 13 May 2016 Journal of Laws 2016, item 846 as amended.

14 Vide: art. $119 \mathrm{a} \$ 3$ of the Tax Ordinance.

15 Vide: art. 119c $\$ 1$ of the Tax Ordinance.

16 Vide: art. $119 \mathrm{c} \$ 2$ pkt 5 of the Tax Ordinance.

17 Vide: Monika Münnich, ”Eelemnty cywilistycznej klauzuli generalnej rozsadku w polskim prawie podatkowym," in Prawo podatkowe w systemie prawa. Międzygatęziowe związki norm i instytucji prawnych, eds. Aneta Kaźmierczyk, and Agnieszka Franczak (Warsaw: Wolters Kluwer, 2019), 137-138. 
at all, or in a limited scale. Therefore, it could not be reasonably expected that in relation to the conduct the decision concerned, which is referred to in section 1 of this paper, the taxpayer will need any professional advice on tax consequences. Additionally, the criterion of reason has also been found in the provisions regulating the institution of tax schemes ${ }^{18}$ since 2018, it reads:

1. (...) on the basis of existing circumstances, it should be assumed that a reasonably functioning promoter or beneficiary to whom the obligations provided for in the provisions of this chapter would not apply, would like at least one of the obligations set out in separate provisions of this Act to be actually respected ${ }^{19}$,

2. the main benefit criterion is considered to be met if, on the basis of existing circumstances and facts, it should be assumed that an entity acting reasonably and with lawful purposes other than achieving tax benefit could legitimately choose other rules of conduct which would not involve a reasonable tax benefit expected or resulting from the implementation of the agreement, and the tax benefit is the main or one of the main benefits that the entity expects to receive in connection with the implementation of the agreement $^{20}$.

In all provisions of the Tax Ordinance, a characteristic of the clause of reasonableness, evaluative and indeterminate expression - reason - was used primarily in relation to a reasonable person, with the focus on the aforementioned basic evaluation standard, i.e. the model of a reasonable and honest man. Undoubtedly, the judgment criterion of reason used in the provisions creates for the legal interpreters, who construct the operative interpretation (i.e. tax authorities and administrative courts), a platform for dynamic interpretation. This is even more important because the common feature of these provisions is their anti-abusive nature.

18 Vide: Sectio III, Chapter 11a of the Tax Ordinance.

19 Vide: art. 86a $\$ 1$ pkt 6 letters a-c and letter $\mathrm{k}$ of the Tax Ordinance.

20 Vide: art. 86a $\$ 2$ of the Tax Ordinance. 


\section{CRITERION OF RATIONALITY AND REASON IN THE INTERPRETATION OF PROVISIONS REGULATING TAX DEDUCTIBLE COSTS}

The criterion of reasonable or rational conduct of the taxpayer is a completely different issue related to the legal structure, that is to tax deductible costs. This institution is normalized in two acts regulating both individual and corporate income tax. According to their content, tax deductible costs are the costs incurred to receive revenue from a revenue source or to maintain or secure a source of revenue, except for the costs listed in separate regulations ${ }^{21}$.

The language interpretation of the provisions cited leads to the conclusion that the condition for recognizing a certain expense as tax-deductible is the existence of two combined circumstances, in which:

- expenditure incurred should be made in order to generate and maintain or secure a source of revenue, and

- the expenditure incurred cannot be included in the negative catalogue, comprising non-deductible expenses ${ }^{22}$.

Unfortunately, provisions regulating the legal definition of tax deductible costs are not correctly and unequivocally formulated, which contributes to the fact that taxpayers who have the basic and widest scope of responsibility for their correct interpretation have had (from the moment this institution started to function in tax law, i.e. in 1991 and 1992) numerous problems with their observance and correct application ${ }^{23}$. The range of tax-

21 Vide: art. 15 point 1 the Act on Corporate Income Tax of 15 February 1992, Journal of Laws 2017, item 2343 as assesmend and art. 22 point 1 the Act on Personal Income Tax of 26 July 1991, Journal of Laws 2018, item 200 as assesmend.

22 This interpretation is confirmed by judicial decisions vide, e.g.: Provincial Administrative Court in Lublin, Judgment of 21 November 2018, Ref. No. I SA/Lu 534/18, reported in: LEX No. 2597373; Supreme Administrative Court, Judgment of 13 November 2018, Ref. No. II FSK 3366/16, reported in: LEX No. 2595528.

23 As a legal definition, the normative construction of tax deductible costs is also considered by: Magdalena Kowalska, and Paweł Borszowski, "Podejmowanie działalności gospodarczej a definicja kosztów podatkowych," Prawo i Podatki, no. 2 (2009): 7-12; Magdalena Kowalska, and Paweł Borszowski, "Racjonalność a pozorność w definicji kosztów podatkowych,” Prawo i Podatki, no. 10 (2008): 7-10; Paweł Borszowski, "Racjonalność i celowość w nowej definicji kosztów podatkowych - glosa do wyroku Naczelnego Sądu Administracyjnego z 18.11.2005 r. (II FSK 182/2005)”, Glosa, no. 2 (2008): 118-124; Pa- 
payer's liability in determining tax deductible costs is all the more difficult to clarify that the analysis of case law and literature indicates at least three directions for interpreting the title legal concept. First of all, both in jurisprudence and individual tax interpretations, and also in literature, the institution of tax-deductible costs is recognized as a general clause ${ }^{24}$.

weł Borsdzowski, Określenia nieostre i klauzule generalne w prawie podatkowym, (Warszawa, Wolters Kluwer: 2017), 27; Paweł Borszowski, "Koszty uzyskania przychodów - pomiędzy elastycznością a definiowaniem," in Dny práva 2016 - Days of law 2016. Část 2, Rekodifikace dani z príjmů: (90 let od Englišovy danové reformy), eds. Petr Mrkývka, Damian Czudek, Jiří Valdhans, (Brno: Masarykova univerzita, 2017), 71-80; C.f. judgments e.g.: Provincial Administrative Court in Poznań, Judgment of 26 Juny 2012, Ref. No SA/Po 216/12, reported in: CBOSA; Supreme Administrative Court in Warsaw, Judgment of 13 November 2018, Ref. No. II FSK 3194/16, reported in: LEX No. 2588096; Provincial Administrative Court in Warsaw, Judgment of 21 December 2014, Ref. No. SA/Wa 695/14, reported in: CBOSA and see tax interpretations: individual interpretation of the Director of the Tax Chamber in Warsaw of 14 December 2015, No. IPPB1/4511-1035/15-2/AM, changed by individual interpretation of 13 December 2016, No. DD9.8220.2.204.2016.JPQ, https://sip.mf.gov.pl (access date 19.03.2019); see also e.g. individual interpretation of the Director of the National Treasury Information of 2 December 2018, No. 0111-KDIB2-3.4010.348.2018.1.APA, https://interpretacje-podatkowe.org/koszty-uzyskania-przychodow/0111-kdib2-3-4010348-2018-1-apa (access date: 19.03.2019).

24 C.f. Supreme Administrative Court, Judgment of 12 May 2016, Ref. No. II FSK 837/14, reported in: CBOSA; Provincial Administrative Court in Poznań, Judgment of 26 June 2012, Ref. No. SA/Po 216/12, reported in: CBSOA; Provincial Administrative Court in Wrocław, Judgment of 16 August 2010, Ref. No. I SA/Wr 678/10, reprted in: CBOSA. See also: individual interpretation of the Director of the National Treasury Information of 2 May 2015, No. 0113-KDIPT2-1.4011.258.2018.1.KO, https://sip.mf.gov. pl (access date: 19.03.2019); individual interpretation of the Director of the Tax Chamber in Warszawa of 27 January 2009, No. IPPB1/415-1312/08-2/EC, https://www.ifirma.pl/ blog/interpretacja-podatkowa-czy-zakup-okularow-korekcyjnych-jest-kosztem-firmy.html (access date: 8.02.2019). C.f.: Paweł Borszowski, Dziatalność gospodarcza w konstrukcji prawnej podatku (Warsaw: Wolters Kluwer , 2010), 171, 206, 263-263, 284, 288, 301; Dawid Michalak," Pojęcie kosztu uzyskania przychodu w orzecznictwie sądów administracyjnych," June 30, 2020, http://www.money.pl/podatki/ip/cit/pojecie-kosztu-uzyskania-przychodu-w-orzecznictwie-sadow-administracyjnych/ (access date: 8.02.2019); Magdalena Jastrowicz,"Ciężar dowodu w zakresie kosztów uzyskania przychodów w podatku dochodowym od osób prawnych," in Podatnik versus organ podatkowy, ed. Paweł Borszowski, Studia Finansowoprawne, no. 2 (2011): 59; Robert Zieliński, "Koszty uzyskania przychodów z działalności gospodarczej osób fizycznych jako bariera rozwoju przedsiębiorców w Polsce wybrane problemy," Krytyka Prawa, no. 5 (2014): 284; Leszek Klecz-kowski, ”Definicja 
Such extremely different qualifications of one legal structure by interpreters in the course of applying the law is not only a dogmatic problem. It concerns the effects and limits of the interpretation of law. The law interpreter may use different interpretative directives in case of legal material definition, and in case of provisions in the general clause referring to non-legal assessments and values. Such a dichotomous vision of the legal structure in question is contrary to the positivist concept of the rational legislator.

Referring to the definition of tax-deductible costs, it should be noted that, according to the intention of the legislator, in the current definition of the legal institution of tax-deductible costs, clear emphasis was placed on the fact that tax costs are only these costs the taxpayer incured in order to:

- generate revenue or

- maintain or secure the source of revenue

as long as they do not belong to the catalogue of negative expenses not qualified as tax deductible costs.

In both jurisprudence and tax publications, the following circumstances are most often indicated as conditions fulfilling the semantic scope of the normative expression "in order to":

1. the costs incurred by the taxpayer shall be related to the gained revenue and shall be definitive ${ }^{25}$;

kosztów uzyskania przychodów jako klauzula generalna," Kwartalnik Prawa Podatkowego, no. 4 (2012): 23-36; Paweł Mikuła, "Zagraniczny podatek od towarów i usług jako przychód i koszt podatkowy," June 30, 2020, https:/www.russellbedford.pl/o-nas/rb-biuletyn/ item/1061-zagraniczny-podatek-od-towarow-i-uslug-jako-przychod-i-koszt-podatkowy. html (access date: 12.03.2019).

25 Włodzimierz Nykiel, and Michał Wilk, "Komentarz do art. 15," in Monika Bogucka-Felczak, Tomasz Kardach, Edyta Klimek, Joanna Kordal, Ziemowit Kukulski, Adam Mariański, Tomasz Miłek, Włodzimierz Nykiel, Dariusz Strzelec, Mikołaj Turzyński, Michał Wilk, Komentarz do ustawy o podatku dochodowym od osób prawnych, eds. Włodzimierz Nykiel, and Adam Mariański, (Warsaw: ODDK, 2014), 344. See also: Provincial Administrative Court in Białymstok, Judgment of 19 May 2004, Ref. No. I SA/ Bk 77/04, reported in: CBOSA. 
2. there shall be a direct or indirect 'cause and effect' relationship between expences and revenue ${ }^{26}$;

3. this relationship shall be properly (reliably) documented ${ }^{27}$.

When assessing the relationship between expenditure and business activity, the taxpayer should assume that a potential cost may objectively contribute to generating revenue. In addition, it should be remembered that the taxpayer recognizing expenses as tax deductible costs has obvious benefits, because the tax base is reduced by this cost. Therefore, the taxpayer bears the material burden of proving that a certain expense is tax deductible. The taxpayer makes economic decisions, taking into account the economic risk and financial resources at his disposal to generate revenues.

This purposefulness of incurring tax costs is usually supplemented with other vague phrases, such as rationality or reasonableness, both in jurisdiction and in literature. It should be emphasized that such an assessment criterion referring to the economic area is not a new interpretative phenomenon. The identification of the taxpayer's purposeful performance

26 C.f.: Adam Mariański, "Brak podstaw do stosowania cywilnoprawnego pojęcia związku przyczynowo-skutkowego jako przesłanki uznania kosztu podatkowego," Przegląd Podatkowy, no. 6 (2006): 13; Włodzimierz Nykiel, Michał Wilk, "Komentarz do art. 15," 344-346; Andrzej Gomułowicz, Prawna formuta kosztu podatkowego (Warsaw: Wolters Kluwer, 2016), 34-35. See also: Supreme Administrative Court, Judgment of 13 November 2018, Ref. No. II FSK 3194/16, reported in: LEX No. 2588096 and similar jurisprudence in the Supreme Administrative Court judgments in cases: II FSK 571/16, II FSK 911/16, II FSK 2609/15, II FSK 1438/06, II FSK 1755/06, II FSK 1405/07, II FSK 418/09, II FSK 462/11, II FSK 1484/15, reported in: CBOSA and Provincial Administrative Court in Białystok, Judgment of 14 November 2018, Ref. No. I SA/Bk 300/18, reported in: LEX No. 2585060; Provincial Administrative Court in Poznań, Judgment of 26 June 2012, Ref. No. SA/Po 216/12, reported in: CBOSA; Provincial Administrative Court in Lublin, Judgment of 21 November 2018, Ref. No. I SA/Lu 534/18, reported in: LEX nr 2597373.

27 Vide: Włodzimierz Nykiel, and Michał Wilk, "Komentarz do art. 15," 354 and Supreme Administrative Court, Judgment of 2 December 1993, Ref. No. SA/Po 2020/93, reported in: CBOSA; Supreme Administrative Court, Judgment of 9 September 1994, Ref. No. III SA 30/94, reported in: CBOSA; Provincial Administrative Court in Rzeszów, Judment of 26 August 2014, Ref. No. I SA/Rz 521/14, reported in: CBOSA; Provinial Administrative Court in Lublin, Judgment of 21 November 2018, Ref. No. I SA/Lu 534/18, reported in: LEX nr 2597373. C.f. also Supreme Administrative Court, Judgment of 13 November 2018, Ref. No. II FSK 3194/16, reported in: LEX nr 2588096. 
with rationality was already evident in court judgments in the second half of the nineties. Without doubt, both in judicial decisions and interpretations of tax authorities, as well as in literature, this interpretative trend is gaining momentum and, instead of examining the "purposefulness" of expenditure, courts and authorities more often analyse circumstances indicating, for example:

- rational ${ }^{28}$ or irrational conduct of the taxpayer ${ }^{29}$,

- rationality of conduct to generate revenue ${ }^{30}$,

- rationality in incurring expenses ${ }^{31}$,

- irrationality of conduct from an economic perspective ${ }^{32}$,

- compliance with the principles of rational reasoning ${ }^{33}$,

- using reason in deducting expenses ${ }^{34}$,

28 C.f Supreme Administrative Court, Judgment of 9 September 1994, Ref. No. III SA 30/94, reported in: Monitor Podatkowy, no. 1 (1995): 18; Provincial Administrative Court in Poznaniu, Judgment of 26 June 2012, Ref. No. SA/Po 216/12, reported in: CBOSA.

29 C.f. Supreme Administrative Court, Judgment of 3 December 2009, Ref. No. III FSJ 1019/08, reported in: CBOSA; indiwidual tax interpreation of the Director of the Tax Chamber in Warszawa of 12 April 2012, No IPPB3/423-35/12-2/GJ, https://www.rp.pl/Podatek-dochodowy/303239998-Koszty-uzyskania-przychodu-fiskus-nie-moze-kwestionowac-racjonalnosci-wydatkow.html (access date 15.03.2019).

30 Vide: Provincial Administrative Court in Wrocław, Judgment of 28 January 2011, Ref. No. I SA/Wr 229/10, reported in: CBOSA.

31 Vide: Provincial Administrative Court in Warszawa, Judgment of 23 July 2004, Ref. No. III 949/03, reported in: CBOSA; Provincial Administrative Court in Olsztyn, Judgment of 21 August 2008, Ref. No. I SA/Ol 273/08, reported in: CBOSA; individual tax interpretaion of the Director of the National Treasury Information of 13 August 2018, No. 0114-KDIP2-2.4010.257.2018.1.SO, https:/sip.mf.gov.pl/faces/views/szczegoly/szczegoly-interpretacji-indywidualnej.xhtml?dokumentId=537837\&poziomDostepu=PUB\&indexAccordionPanel=-1\#tresc (access date: 15.05.2019).

32 Vide: Provincial Administrative Court in Lublin, Judgment of 29 November 2004, Ref. No. I SA/Lu 234/04, reported in: CBOSA.

33 C.F.: Supreme Administrative Court, Judgments of: 3 December 2009, Ref. No. III FSJ 1019/08; 7 June 2011, Ref. No. II FSK 462/11; 23 October 2012, Ref. No. II FSK 946/11; 27 February 2013, Ref. No. II FSK 1391/11; 19 August 2016, Ref. No. II FSK 1923/14, reported in: CBOSA.

34 Vide i.g.: Supreme Administrative Court, Judgments of: 9 February 2001, Ref. No. I SA/Gd 1367/98 and 17 June 2003, Ref. No SA/Bd 1818/01, reported in: CBOSA. 
- rationality and economic justification of expenses related to business operations ${ }^{35}$.

It should be noted that both concepts of rationality and reason are not standardised in provisions regulating the content of tax-deductible costs. These are typical expressions in literature, so called estimated returns of economic provenance, the purpose of which is to enable an individual assessment of the taxpayer's operation in a particular situation. Both in judicial decisions and in tax interpretations, these semantic evaluation criteria used in various configurations: rational/ irrational expenditure, conduct or reason are generally not explained, so in consequence the interpreters are limited to their basic linguistic meaning.

As a rule, court judgments indicate that the rational conduct of an entrepreneur is understood as an activity performed on the basis of the state of knowledge the taxpayer had at the time of incurring the expenditure, taking into account the high probability of revenue ${ }^{36}$. Both tax authorities and courts, very often interpreting tax deductible costs as justified, consider only rationally and economically justified expenses and expenses related to the economic activity of the taxpayer who, by incurring them ("in order to") aims to gain revenue from this source. In the jurisdiction, it is asserted that the taxpayer should demonstrate this purposefulness of incurring expenditure, and above all, that the expenditure was incurred rationally, i.e. that the taxpayer in return for this expenditure, has actually

35 Vide: individual tax interpretation of the Director of the Tax Chamber in Warszawa of 27 October 2010, No. IPPB3/423-500/10-2/JG, https://e-prawnik.pl/interpretacje-podatkowe/ippb3423-50010-2jg.html (access date 15.05.2019); individual tax interpretaion of the Director of the National Treasury Information of 13 September 2018, No. 0114-KDIP2-2.4010.257.2018.1.SO., https://www.podatki.biz/artykuly/koszty-uzyskania-przychodow-wydatki-refakturowane-przez-podmoty-wspolpracujace_14_39372. htm (access date: 15.05.2019). C.f. Provincial Administrative Court in Lublin, Judgment of 10 August 2017, Ref. No. I SA/Lu 380/17, reported in: CBOSA.

36 Vide: Provincial Administrative Court in Warsaw, Judgment of 23 June 2009, Ref. No. III SA/Wa 460/09; Supreme Administrative Court, Judgment of 14 August 2003, Ref. No. SA/Bd 1627/03, both avilable on: CBOSA; Provincial Administrative Court in Olsztyn, Judgment of 21 December 2007, Ref. No. I SA/Ol 534/07, reported in: LEX No. 39954. 
obtained certain goods and that they could rationally or at least hypothetically generate revenue ${ }^{37}$.

The analysis of cited legal judgements clearly indicates that the judgemental and vague rationality criterion of conduct or reason, in incurring expenses, is interpreted by the courts through the prism of praxeology, i.e. the science of conscious and intentional human activity. This way of understanding the rationality of taxpayer's conduct actually directs the interpreting entity to an objective method of assessing taxpayer's conduct. In other words, the rationality of taxpayer's conduct is understood technically by national administrative courts. Rational conduct is the one, that takes into account the objective possibility of generating revenue or maintaining or securing the source of revenue.

Consequently, the question arises why in recent years tax authorities and courts, when assessing taxpayers' conduct and determining the scope of their responsibility regarding the amount and legitimacy of costs incurred, place such a considerable emphasis on issues related to the rationality of taxpayer's conduct and reasonableness in going to expenses.

It seems that there are several reasons that can be compressed to one conclusion, dangerous for the taxpayer and justified on fiscal grounds. The economic reality is becoming more and more complex and eluding traditional normative constructions containing a limited number of vague phrases, such as the definition of tax-deductible costs, which is quite hermetic and casuistic in comparison with other recent tax solutions. In consequence, it seems to be less and less applicable to the emerging new forms and economic correlations enabling the taxpayers to make progressive economic turnover.

Therefore, the entities making interpretations recognise that this literal content of the provisions indicates that the expense incurred "in order to achieve, maintain and secure...", should be made more flexible and should

37 Zob.: individual tax interpretation of the Director of the Tax Chamber in Poznań of 22 November 2011, No. ILPB3/423-401/11-2/EK; individual tax interpretation of the Director of the National Treasury Information of 13 August 2018, No. 0114-KDIP2-2.4010.257.2018.1.SO; Voivodship Administrative Court in Lublin, Judgment of 10 August 2017, Ref. No. I SA/Lu 380/17, reported in: CBOSA. 
be interpreted by means of more open meaningful terms referring to the area of rational, reasonable and economically justified taxpayer's conduct.

\section{CONCLUSIONS}

All things considered, it must be noted that the excessive use of the estimated returns with strictly economic origin in the interpretation of the legal definition of deductible costs can have far-reaching consequences for taxpayers. Without doubt, traditional normative constructions of tax law, typical of public law, have been undergoing fundamental transformation lately. This process involves absorbing and using autonomously solutions typical of private law. This phenomenon occurs bipolarly. Firstly, it takes place, as indicated in this paper, in a traditional way, i.e. in the process of tax law-making. Secondly, however, certain solutions typical of both private law norms and its legislation are transplanted into tax law in the course of its application. The best example of this procedure is the introduction of the civil law clause of good faith into the European VAT system by CJEU case - law.

It is predictable that in the near future it may turn out that the application of both judicial and administrative practice will contribute to the desirable legislative solution for purely pragmatic reasons. There may be such a change in the content of the regulations on tax costs, that the present legal definition will be replaced with a new normative construction based on the general clause of reasonableness. Under the existing jurisprudence doctrines, it can be assumed that the content of the new provisions could read as follows: tax deductible costs are reasonable and economically justified costs incurred to generate revenue from the source of revenue or to preserve, or secure the source of revenue. Undoubtedly, the proposed technical and legislative change would allow taxpayers or tax authorities, and courts to assess expenditure on the basis of purposeful or rather economic interpretation of the two essential expressions, i.e. reasonable and economic justification of the expenses incurred. However, such a change should be preceded by in-depth theoretical and legal research on the directions of interpretation of the clause of reasonableness, which is barely known in Poland. 


\section{REFERENCES}

Amielańczyk, Krzysztof. "W poszukiwaniu antycznej genezy klauzul generalnych, czyli o wartościach i wartościowaniu w prawie rzymskim." Annales Universitatis Mariae Curie-Sklodowska Lublin-Polonia, no. 2 (2016): 27-41.

Bierć, Andrzej. Zarys prawa prywatnego. Część ogólna. Warsaw: C.H. Beck, 2018. Borszowski, Paweł. "Koszty uzyskania przychodów - pomiędzy elastycznością a definiowaniem." In Dny práva 2016 - Days of law 2016. Cást 2, Rekodifikace dani z príjmĩ: (90 let od Englišovy danové reformy), edited by Petr Mrkývka, Damian Czudek, Jiř́ Valdhans, 71-80. Brno: Masarykova univerzita, 2017.

Borszowski, Paweł. "Racjonalność i celowość w nowej definicji kosztów podatkowych - glosa do wyroku Naczelnego Sądu Administracyjnego z 18.11.2005 r. (II FSK 182/2005).” Glosa, no. 2 (2008): 118-124.

Borszowski, Paweł. Dziatalność gospodarcza w konstrukcji prawnej podatku. Warsaw: C.H. Beck, 2010.

Borszowski, Paweł. Określenia nieostre i klauzule generalne w prawie podatkowym. Warsaw: C.H. Beck, 2017.

Bukowska, Natalia. "Klauzula rozsądku w anglosaskim prawie ubezpieczeniowym oraz Restatement of European Insurance Contracts," June 30, 2020. https:// docplayer.pl/7021643-Klauzula-rozsadku-w-anglosaskim-prawie-ubezpieczeniowym-oraz-restatement-of-european-insurance-contracts.html.

Dajczak, Wojciech. Dobra wiara jako symbol europejskiej tożsamości prawa. Poznań: Wydawnictwo Świętego Wojciecha, 2006.

Hesslink, Martijn W. The New European Private Law. Deventer: Wolters Kluwer, 2001.

Jastrowicz, Magdalena. "Ciężar dowodu w zakresie kosztów uzyskania przychodów w podatku dochodowym od osób prawnych." In Podatnik versus organ podatkowy, edited by Paweł Porszowski, Studia Finansowoprawne no. 2 (2011): 59-67.

Kleczkowski, Leszek. ”Definicja kosztów uzyskania przychodów jako klauzula generalna." Kwartalnik Prawa Podatkowego, no. 4 (2012): 23-36.

Kowalska, Magdalena, and Paweł Borszowski. "Racjonalność a pozorność w definicji kosztów podatkowych." Prawo i Podatki, no. 10 (2008): 7-10.

Kowalska, Magdalena, and Paweł Borszowski. „Podejmowanie działalności gospodarczej a definicja kosztów podatkowych." Prawo i Podatki, no. 2 (2009): 7-12.

Law, Stephanie. „From Multiple Legal Cultures to One Legal Culture Thinking About Culture Tradition and Identity in European Private Law Development." Utrecht Journal of International and European Law 31 (2015): 68-89. http://doi.org/10.5334/ujiel.dg. 
Michalak, Dawid. "Pojęcie kosztu uzyskania przychodu w orzecznictwie sądów administracyjnych.” June 30, 2020. http://www.money.pl/podatki/ip/cit/pojecie-kosztu-uzyskania-przychodu-w-orzecznictwie-sadow-administracyjnych/.

Mikuła, Paweł. "Zagraniczny podatek od towarów i usług jako przychód i koszt podatkowy." https:/www.russellbedford.pl/o-nas/rb-biuletyn/item/1061-zagraniczny-podatek-od-towarow-i-uslug-jako-przychod-i-koszt-podatkowy.html.

Monateri, Pier Giuseppe, and Tomasz Giaro, Alessandro Somma. Le radici comuni del diritto europeo. Un cambiamento di prospettiva. Rome: Carroci Editore, 2005.

Münnich, Monika. "Elementy cywilistycznej klauzuli generalnej rozsadku w polskim prawie podatkowym." In Prawo podatkowe w systemie prawa. Międzygatęziowe zwiazki norm i instytucji prawnych, edited by Aneta Kaźmierczyk, and Agnieszka Franczak, 129-139. Warsaw: Wolters Kluwer, 2019.

Pacocha, Monika. "Zastosowanie zasad międzynarodowych kontraktów handlowych UNDROIT jako ogólnych zasad prawa oraz lex mercatoria." https:// repozytorium.amu.edu.pl/bitstream/10593/13559/1/14_PACOCHA.pdf.

Piasecki, Kazimierz. Kodeks cywilny. Księga pierwsza. Część ogólna. Komentarz. Cracow: Zakamycze, 2003.

Pyziak-Szafnicka, Małgorzata. "Komentarz do art. 7.” In Kodeks cywilny. Komentarz. Część ogólna, edited by Małgorzata Pyziak-Szafnicka, and Paweł Księżak. Warsaw: Wolters Kluwer, Lex 2014.

Rott-Pietrzyk, Ewa. "Holenderska klauzula rozsądku i słuszności na tle innych uregulowań prawnych (wzór dla polskiego ustawodawcy?).” Przegląd Prawa Prywatnego, no. 3 (2006): 57-101.

Rott-Pietrzyk, Ewa. "Pojęcie rozsądku w projekcie Europejskiego Kodeksu Cywilnego." In Rozprawy prawnicze. Ksiega pamiattkowa Profesora Maksymiliana Pazdana, edited by Wojciech Popiołek, Leszek Ogiegła, and Maciej Szpunar, 701-718. Cracow: Zakamycze, 2005.

Rott-Pietrzyk, Ewa. "Wzorzec rozsądnej osoby w świetle Konwencji wiedeńskiej o umowach międzynarodowej sprzedaży towarów." Rejent, no. 9 (2005): 202-222.

Zieliński, Robert. "Koszty uzyskania przychodów z działalności gospodarczej osób fizycznych jako bariera rozwoju przedsiębiorców w Polsce - wybrane problemy." Krytyka Prawa, no. 5 (2014): 281-300. 